\title{
Indirect vector control for induction motor drive using two level and five level inverter
}

\author{
Ankit Agrawal, Rakesh Singh Lodhi, Pragya Nema \\ Electrical \& Electronics Engineering, Oriental University, India
}

\begin{tabular}{l}
\hline \hline Article Info \\
\hline Article history: \\
Received Oct 9, 2018 \\
Revised Dec 17, 2018 \\
Accepted Dec 31, 2018 \\
\hline Keywords: \\
Indirect vector control \\
MATLAB \\
Multilevel inverter \\
Simulink \\
Squirrel cage induction motor \\
\hline
\end{tabular}

\begin{abstract}
This paper represent modelling \& simulation of indirect vector control for induction motor drive using two level and five level inverter. To overcome of lower order harmonics, THD \& speed torque characteristics of three phase squirrel cage induction motor. This paper provides solution through indirect vector control \& SPWM technique for multilevel inverter. A comparison and performance of two level and five level inverter are used in motor to control speed, current and torque. Matlab simulation environment are taken to simulate indirect vector control for induction motor drive using two level and five level inverter, so torque ripple minimization, lower order harmonics are reduced, constant speed, constant torque and variable speed variable torque are determined through simulation results. The applications under operating conditions are performed better THD, better reliability in AC drives.
\end{abstract}

Copyright () 2019 Institute of Advanced Engineering and Science. All rights reserved.

\section{Corresponding Author:}

Ankit Agrawal,

Electrical \& Electronics Engineering,

Oriental University,

Jakhiya, Opp. Rewati Range, Gate No. 1, Sanwer Road, Indore, India.

Email: ankit.agrawal1432d@gmail.com

\section{INTRODUCTION}

Induction motors are widely used every production process today [1]. Indirect vector control induction motor drive has been developed, which provide quick torque \& good dynamic responses near zero speed and high speed [2]. There are various method of control speed of induction motor, i.e. stator voltage control, frequency control method, rotor resistance control, EMF injection method, pole changing method [3]. Implementations of two level inverter and a multilevel inverter for vector control of a three phase induction motor drive. Performance of the conventional SPWM based vector controlled indirect field oriented control induction motor drive employing a multilevel inverter from the view point of torque ripple minimization. The vector control technique allows a squirrel cage induction motor to be driven with high dynamic performance that is comparable to the characteristic of dc motor. Now DC motor torque is directly proportional to the field current and armature as like Squirrel cage Induction motor torque is directly proportional to the direct axis component and quadrature axis component and both are independent and perpendicular.

DC power is the constant value power does not change with time. Here we are use two type of DC voltage; In scalar control techniques use direct DC voltage and for vector control scheme DC voltage from AC supply using uncontrolled rectifier and filter. Two and five level of Inverter in vector control scheme. Which convert Fix DC voltage to AC voltage which near to the fundamental voltage with 50 Hertz frequency. Squirrel cage induction motor is directly connected to the inverter and load connects to the squirrel cage induction motor. 


\section{INDIRECT VECTOR CONTROL OF INDUCTION MOTOR DRIVE}

Main features of vector control of IM drives are higher transient current capability, increased speed range and lower inertia. The block diagram of indirect vector control for induction motor drive is shown in Figure 1. Power modulators of AC drives are two level \& five level are used. In Figure 2, circuit configuration of vector control of induction motor drive are shown.

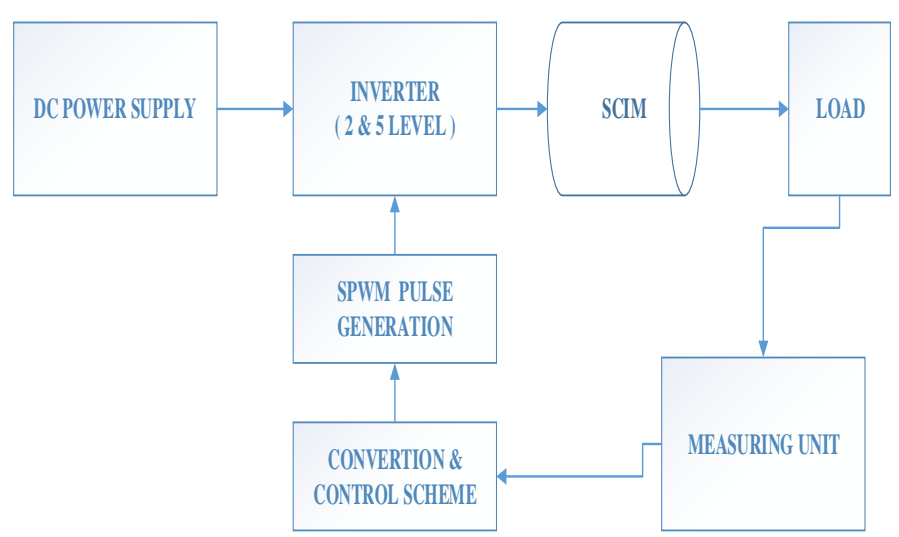

Figure 1. Block diagram of vector control of induction motor drive

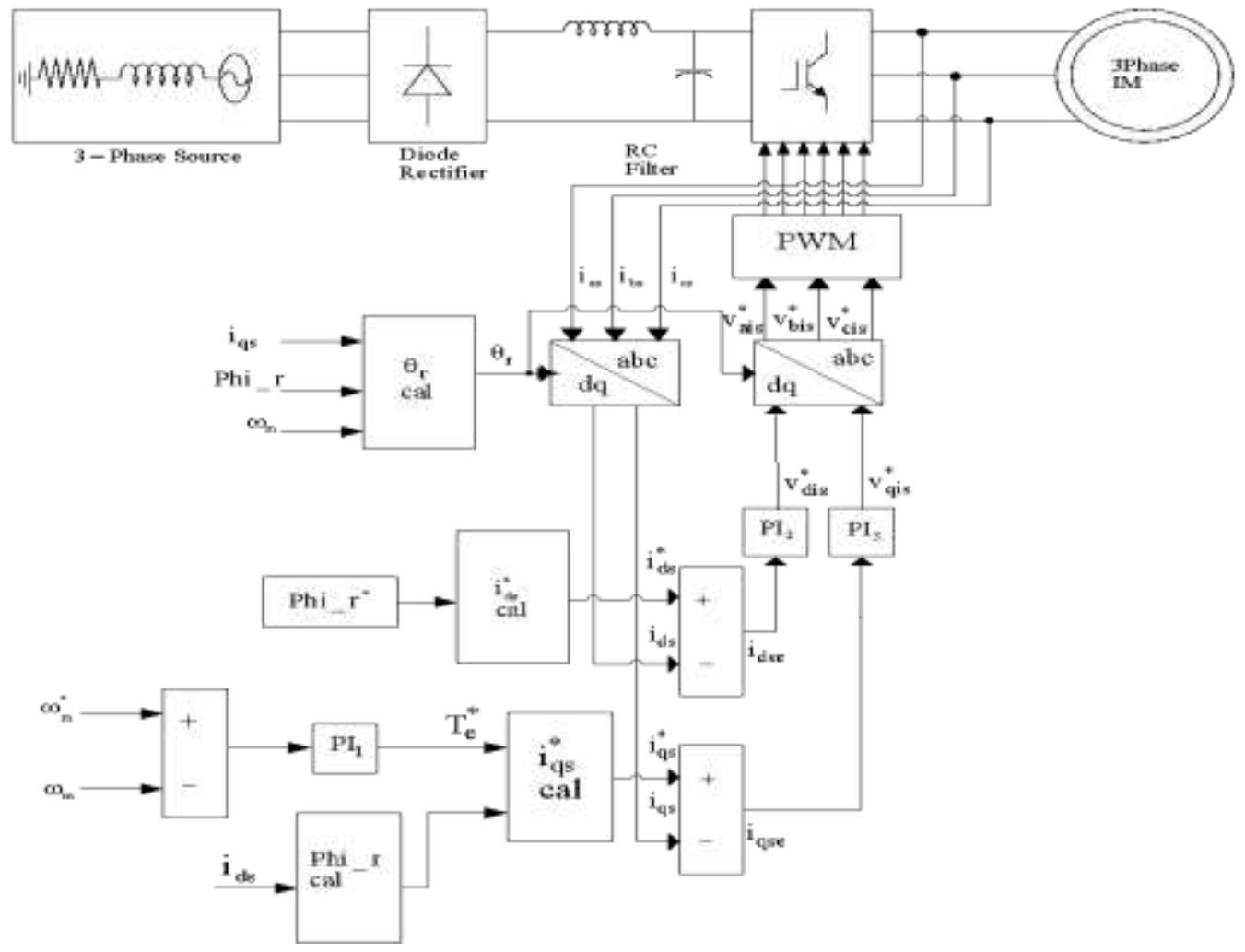

Figure 2. Circuit configuration of vector control of induction motor drive

\section{PROPOSED METHODOLOGY}

Indirect vector control of induction motor drive is applied to obtain speed, THD of two level inverter and five level inverter. In Figure 3 flow chart of process which is followed for speed control of squirrel cage induction motor. 


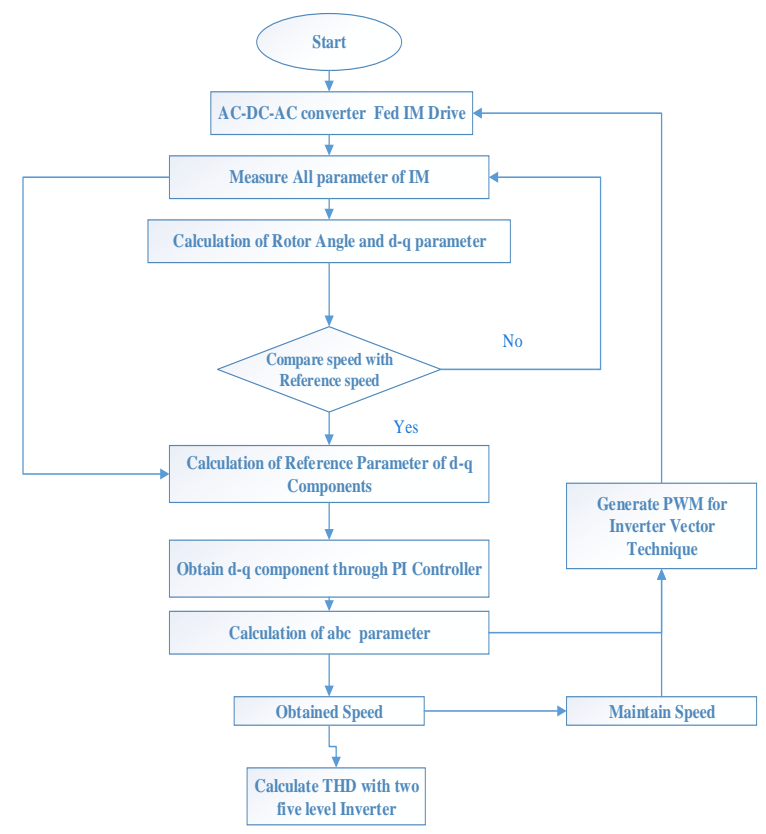

Figure 3. Flow chart of vector control induction motor drive

\section{SIMULATION MODEL}

Two level inverter fed induction motor drive are described through MATLAB / SIMULINK. In this section the MATLAB based model of vector control of induction motor drive has been given in Figure 4. A two level VSI is used which is controlled to run the machine in vector control mode. A model of two level inverter is shown in Figure 5. The reference torque is generated by processing speed error. Actual motor speed is compared with the reference speed and the speed error is processed through a PI controller to generate reference torque component.
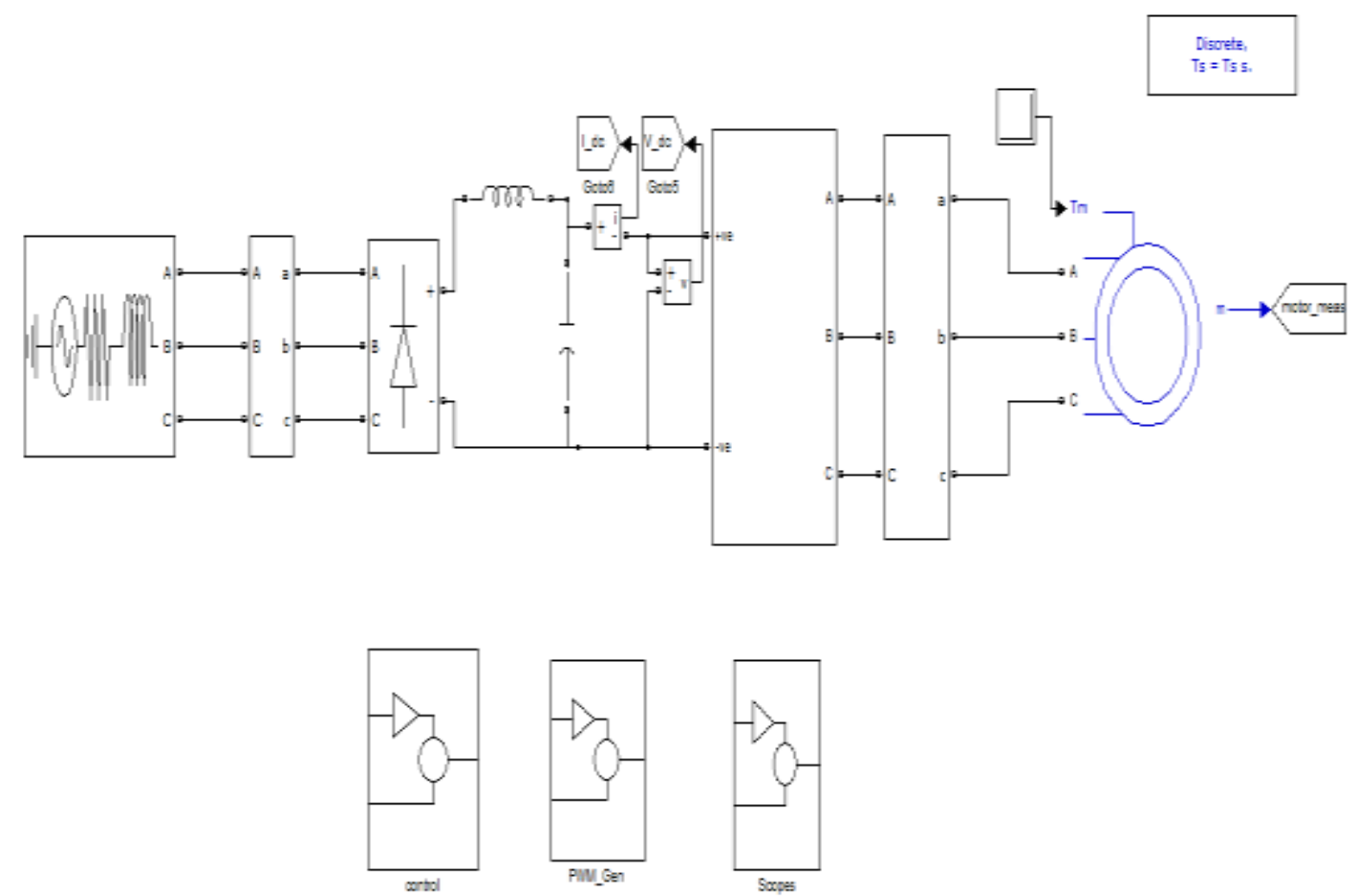

Figure 4. Simulink model of two level inverter induction motor drive 
In Subsystem all mathematical expression as well as their Simulink model are represented below. PI controller is used as speed controller, torque controller and current controller.

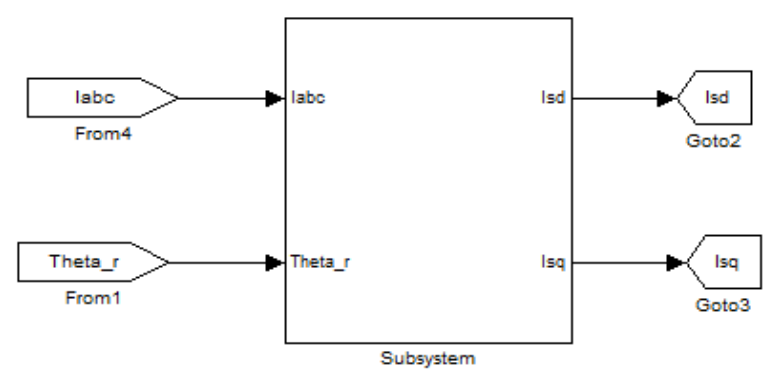

The current $I_{q s}$ and $I_{d s}$ can be resolved into $I_{a}, I_{b}, I_{c}$ components. By ignoring zero-sequence component, it can be simplified as

$$
\begin{aligned}
& I_{s q}=\frac{2}{3} I_{a}-\frac{1}{3} I_{b}-\frac{1}{3} I_{c} \\
& I_{s q}=\frac{2}{3} I_{a}-\frac{1}{3} I_{b}-\frac{1}{3} I_{c}
\end{aligned}
$$

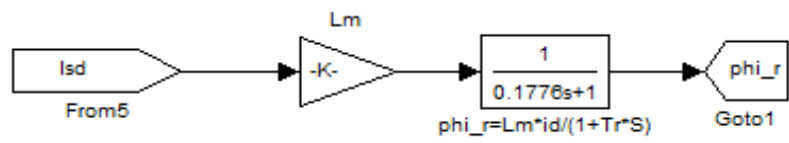

$\emptyset_{r}=L_{m} * \frac{I_{S d}}{1+T_{r} * S}$

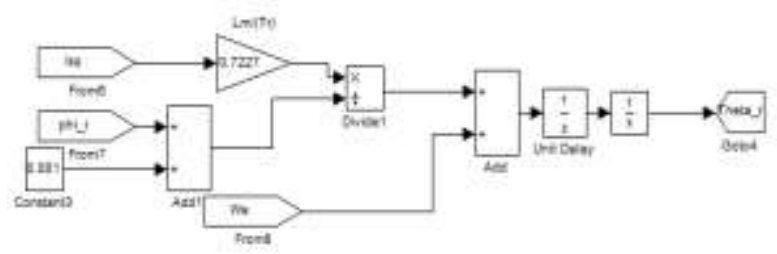

$\omega_{e}=P \omega_{r}+\left(L_{m} / T_{r}\right) *\left({ }^{I}{ } / \emptyset_{r}\right)$

$\theta_{r}=\int \omega_{e} d t$ Elect. $\operatorname{Rad}$

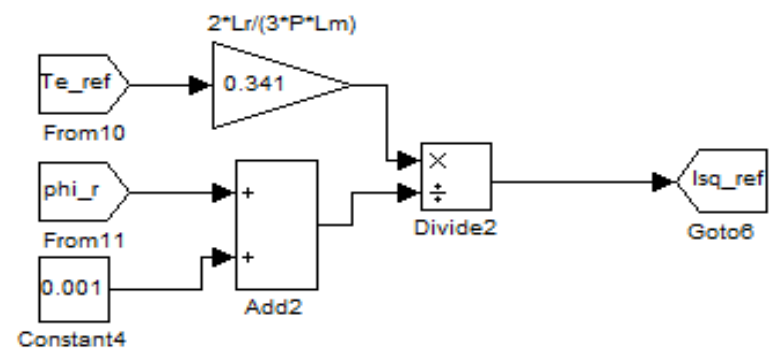

$T_{e_{-} r e f}=\left(\frac{\left(2 * P * L_{m}\right)}{3 * L_{r}}\right) * I_{s q_{-} r e f} \emptyset_{r}$ 


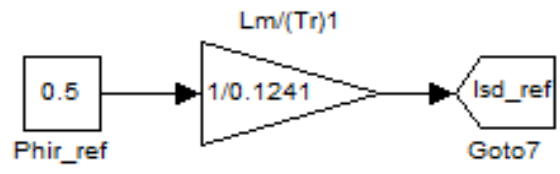

$\emptyset_{r d}=L_{m} I_{s d} / L_{r}$

If induction motor working on rotor flux constant,

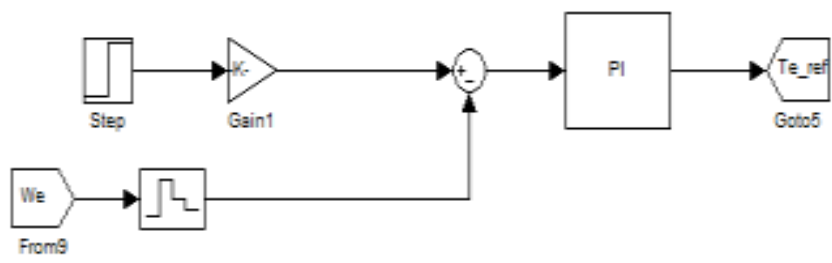

$T_{e}=\omega_{e_{-} r e f}-\omega_{e}$
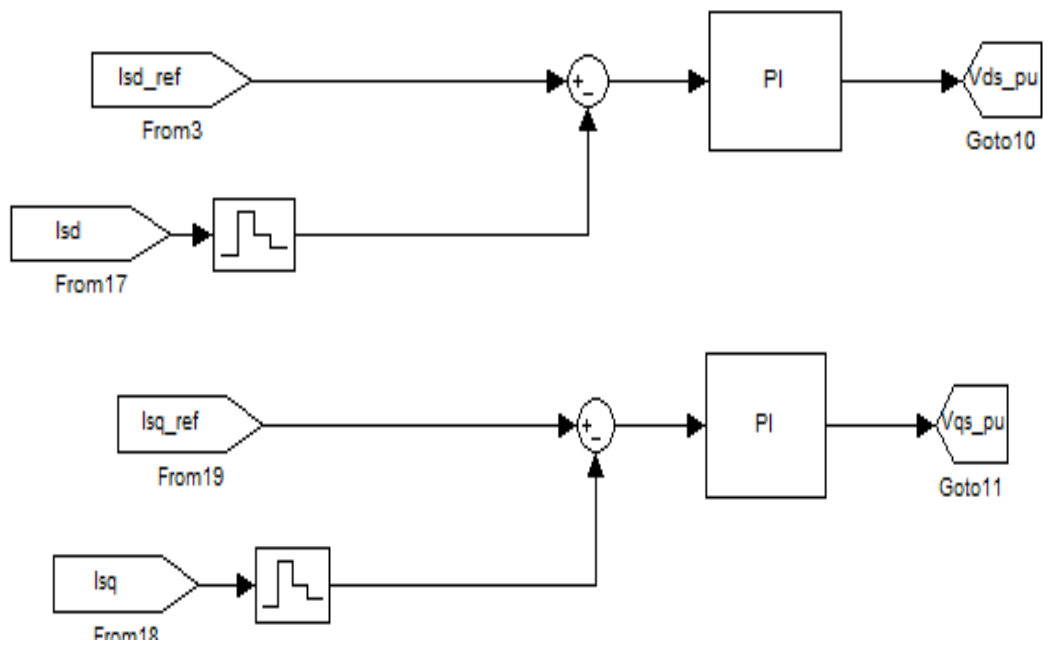

$V_{d s_{-} p u}=I_{s d \_r e f}-I_{s d}$

$V_{d s_{-} p u}=I_{s d_{-} r e f}-I_{s d}$

SPWM generator subsystem compare two signal first one is carrier signal second is reference signal and get the pulse which fed into the inverter switch. Reference signal is come from control subsystem which is varying with respect to desire IM speed.

The system configuration of a squirrel cage induction motor drive. Squirrel cage induction motor of $10 \mathrm{HP}$ rating has been employed. To facilitate the variable speed operation of the drive it has been fed from a multilevel SPWM inverter. Inverter is being supplied by an uncontrolled rectifier filtered with an LC filter fed from a conventional three phase supply of $500 \mathrm{~V}, 50 \mathrm{~Hz}$. The converters have been connected with a common DC link. The voltage source inverter has been controlled using SPWM technique for inverting operation. The VSI is connected to three phase squirrel cage induction motor. The objective of the voltage source inverter is to control the speed of squirrel cage induction motor using vector control scheme. 


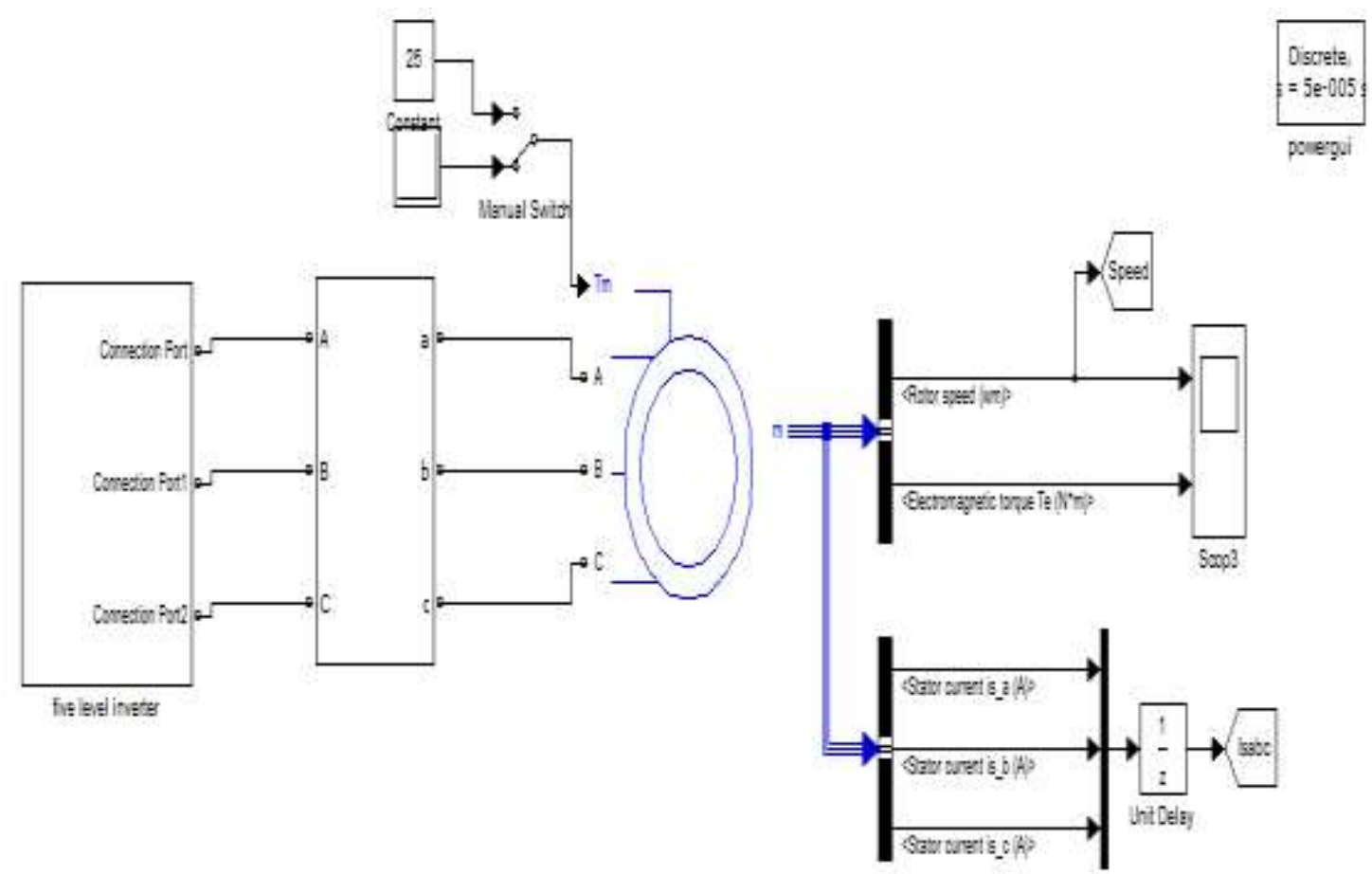

Figure 5. Simulink model of five level inverter induction motor drive

The multilevel inverter controls the speed of the SCIM under constant and variable speed and load. The control scheme employed for multilevel SPWM inverter. Control subsystem for five level voltage source inverter which is control all parameters of IM drive. Here implementing all necessary mathematical expression to obtain desired value of all parameter which is used for the pulse generation. In PWM subsystem through compare signal with triangular wave and sinusoidal wave form as shown in Figure 6. Sinusoidal wave come from the control block which is reference signal and fed to the inverter Switch which control the output parameter.

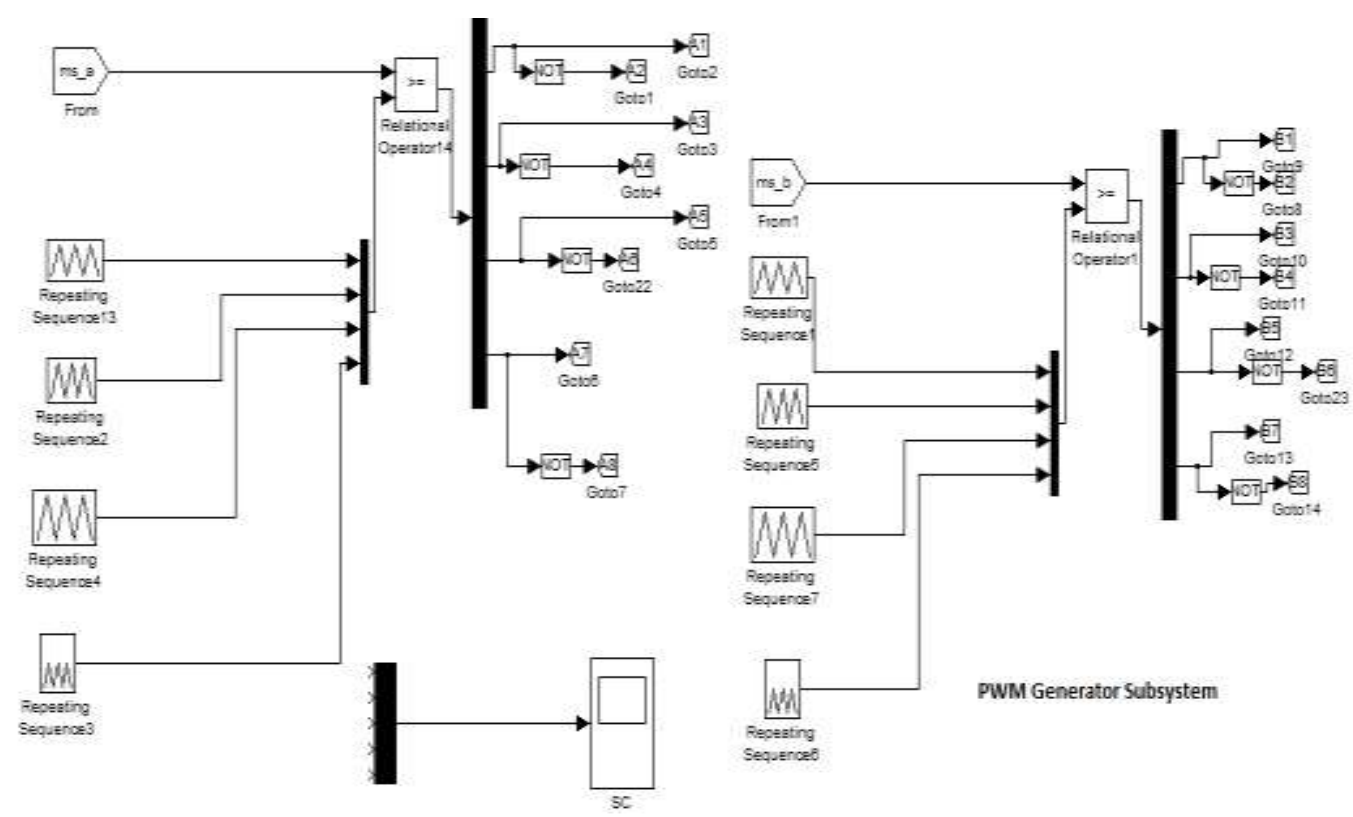

Figure 6. SPWM generation subsystem model of five level inverter fed induction motor drive 


\section{RESULTS ANALYSIS}

Figure 7 represents the voltage (Vabc) and Current (Iabc) w.r.t. time. Initial voltage is low than after some time increases after some time voltage is maintain constant. Current is initial very high than after torque apply current is low and after some time current also maintain constant.

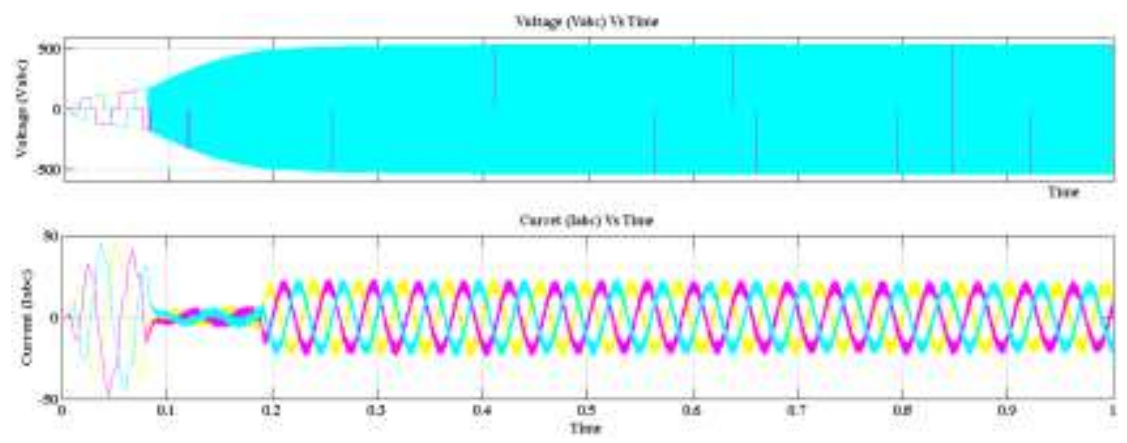

Figure 7. Voltage \& current responses of system under constant torque

The speed of IM at $156 \mathrm{rps}$ which is the rated reference speed. The electromagnetic torque $\left(\mathrm{T}_{\mathrm{e}}\right)$ developed has been meeting the demand of the load torque $\left(\mathrm{T}_{\mathrm{L}}\right)$ which is a function of speed as evident from the results as shown in Figure 8.

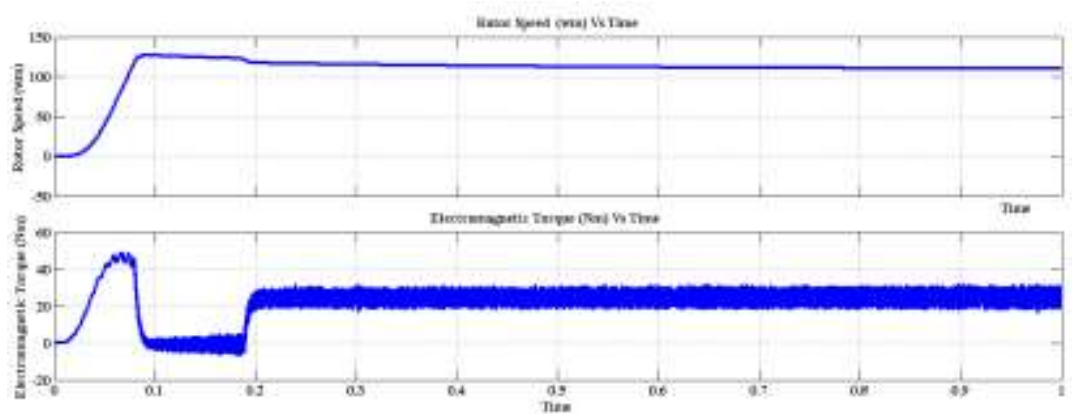

Figure 8. Rotor speed \& electromagnetic torque at constant torque

Figure 9 shows the voltage and current wave form under the variable torque. When torque is not apply voltage going up and current is approx. zero because of load is not connected. When apply torque voltage going to stable condition after some time voltage is stable.

Figure 10 represents the speed of IM motor with the variable torque when torque is not applying speed is going to down with respect to torque. Rated Torque is applying than speed is maintained.

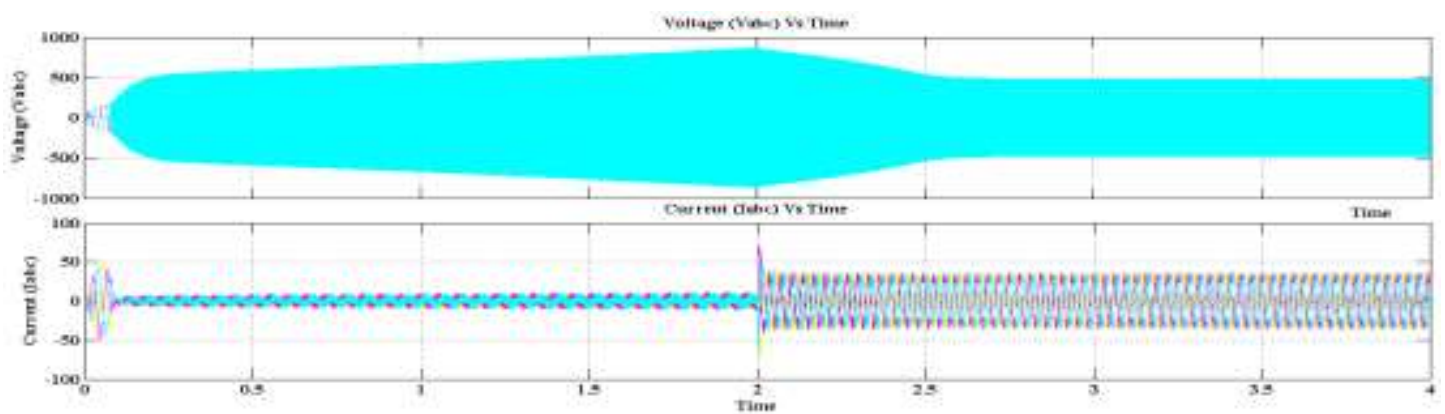

Figure 9. Voltage \& current responses of system under variable torque 

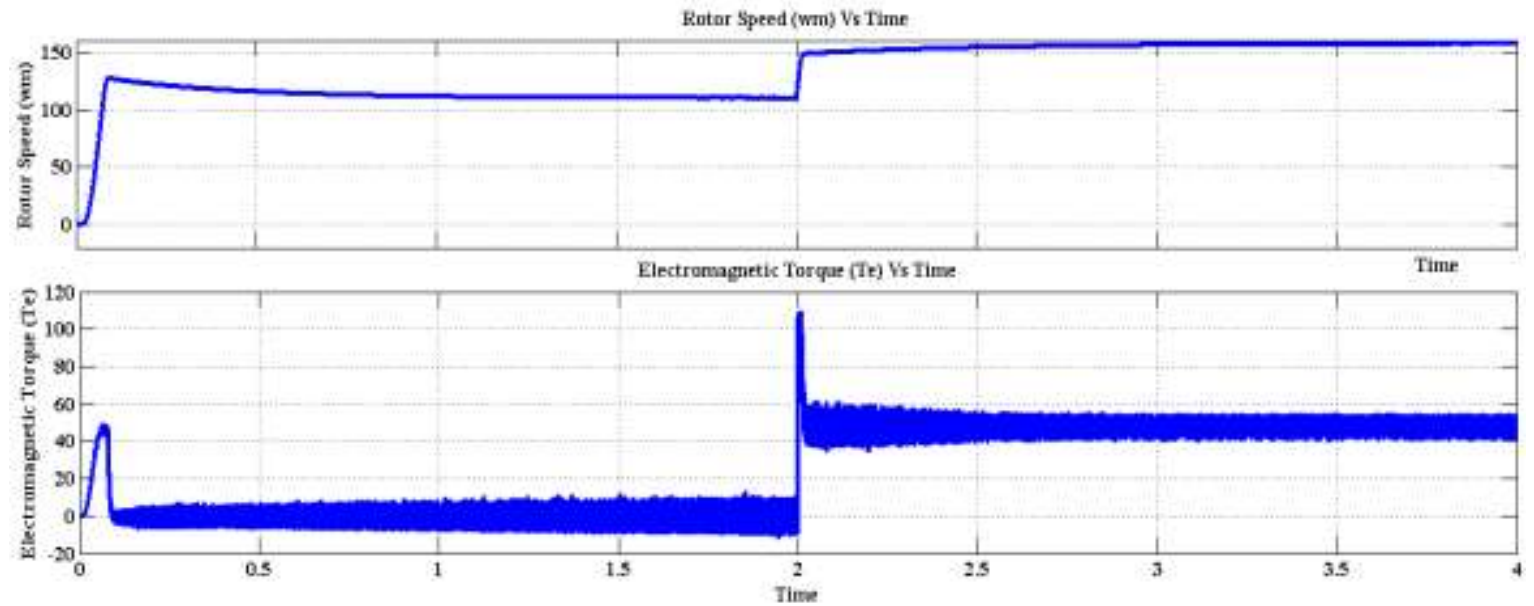

Figure 10. Rotor speed \& electromagnetic torque at variable torque

The drive is running at $156 \mathrm{rps}$ which is the rated reference speed. The electromagnetic torque $\left(\mathrm{T}_{\mathrm{e}}\right)$ developed has been meeting the demand of the load torque $\left(\mathrm{T}_{\mathrm{L}}\right)$ which is a function of speed as evident from the results. Output voltage and current of five level voltage source inverter fed induction motor at different value of torque. The load torque variation of voltage and current with respect to applying torque, which is shown in Figure 11.

The speed and torque in five level VSI fed IM initial speed is very high without applying load torque when applying torque speed will take less time for maintain the rated speed as compare to the two level inverter as shown in Figure 12. Figure 13 shows the voltage and current showing of five level voltage Source Inverter is connected to Induction Motor at variable load torque is also shown.

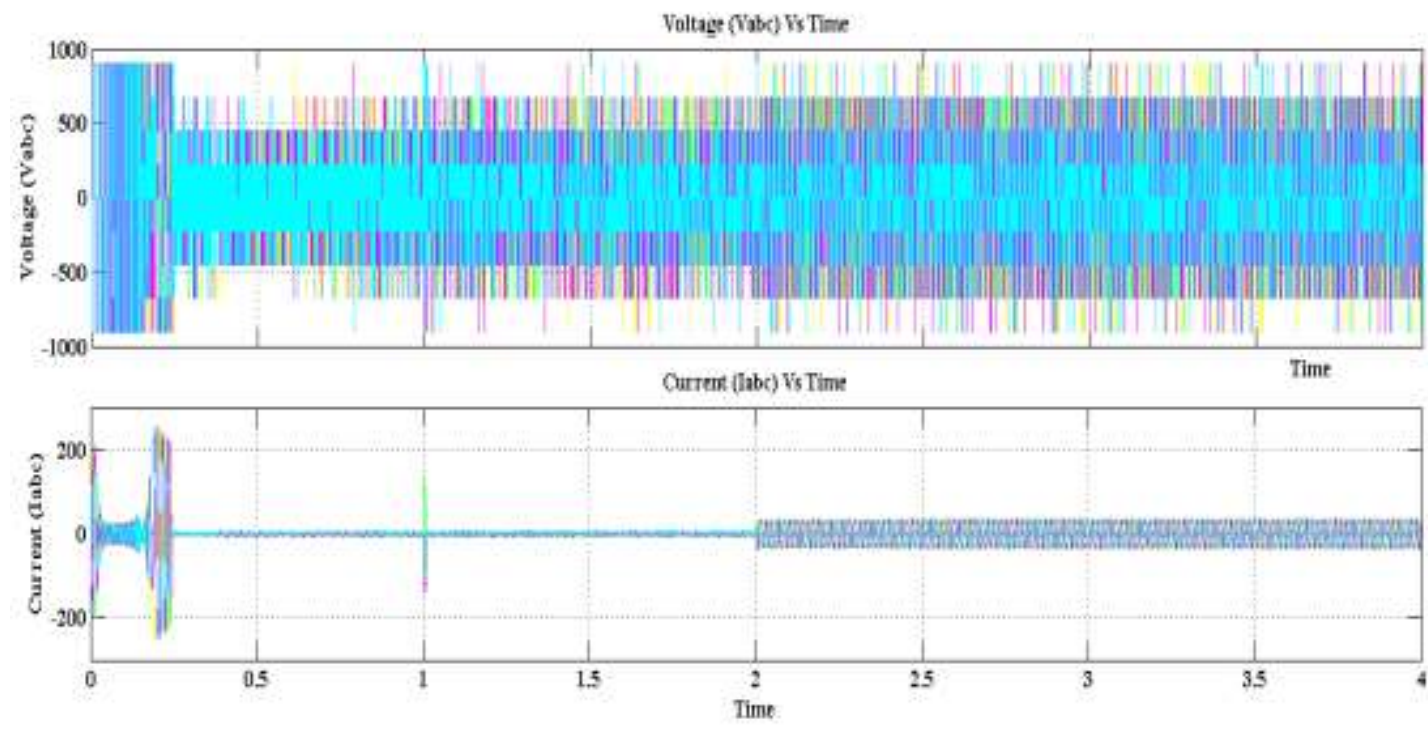

Figure 11. Votage \& current response at variable torque 


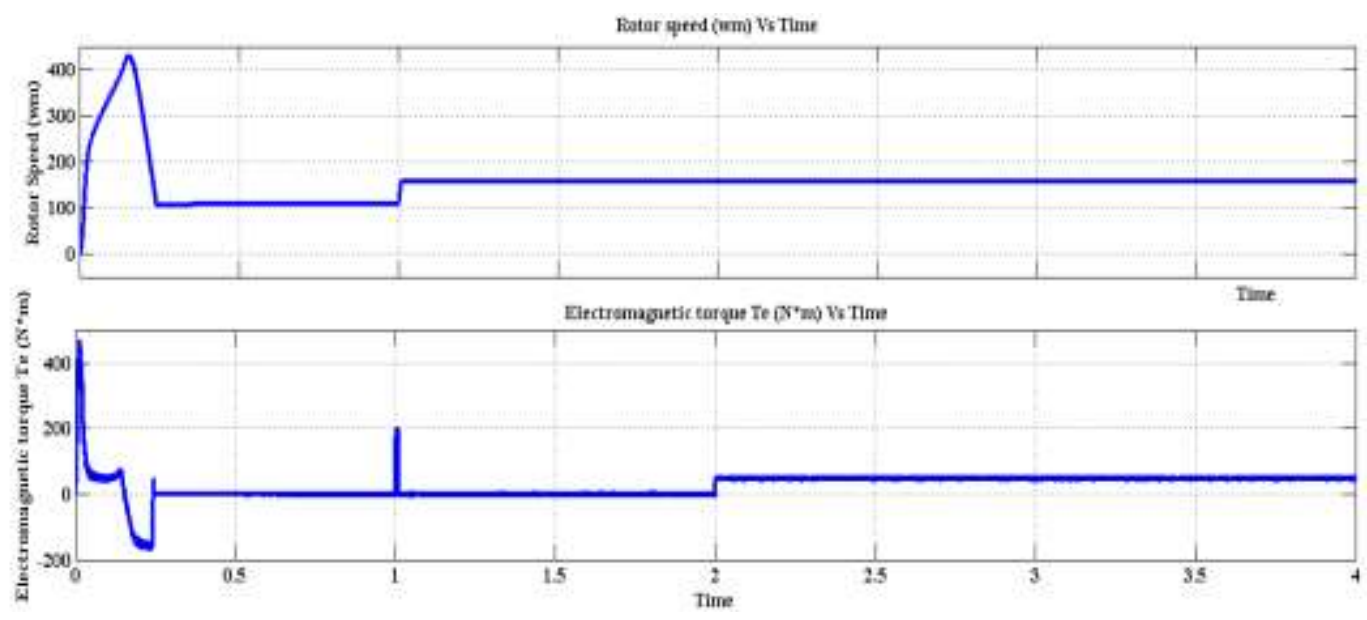

Figure 12. Speed and torque of motor at variable torque

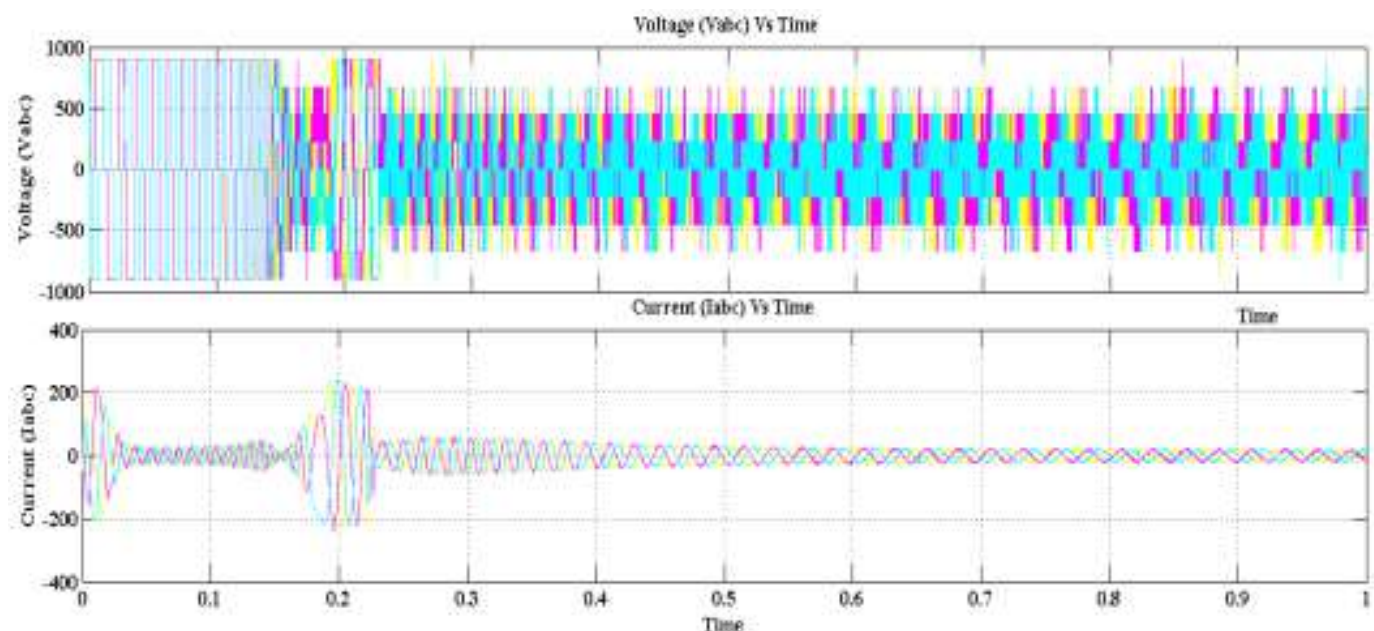

Figure 13.Voltage and current response at constant torque

The five level vector control inverter is slightly a good approach compare to two level inverter for controlling of Induction Motor because direct and quadrature axis component varied accordingly to get the desired speed and torque. Variable torque operation of an Induction Motor drive system using a five and two level voltage source converter. The performance of the SCIM drive has been found satisfactory under change load torque in MATLAB / SIMULINK environment.

The vector control scheme is a good approach for controlling the IM because the IM response to torque change is very quick and precise. Control scheme has been studied for variable torque operation of an Induction Motor drive system.

Table 1 shows that in 5 level inverter, the THD Is less as compared to 2 level inverter. Table 2 shows comparison of torque characteristics for two level and multi level. Table 3 show the various parameter of two and five Level Inverter, thus it is more efficient and reliable as compared to 2 level controllers. Table 3 shows comparison between two inverters and their THD. Two level inverter THD is $86.80 \%$ which is higher than five level multilevel inverter. So, harmonic content is minimum for five level inverter.

Table 1. THD Results for Vector 2 Level \& Vector 5 Level Speed Control Technique

\begin{tabular}{cccccc}
\hline Inverter & THD \% & $\begin{array}{c}1^{\text {st }} \text { Order } \\
\text { Harmonic }\end{array}$ & $\begin{array}{c}3^{\text {rd }} \text { Order } \\
\text { Harmonic }\end{array}$ & $\begin{array}{c}5^{\text {th }} \text { Order } \\
\text { Harmonic }\end{array}$ & $\begin{array}{c}7^{\text {th }} \text { Order } \\
\text { Harmonics }\end{array}$ \\
\hline 2 level & 86.80 & 100 & 36.15 & 22.72 & 15.05 \\
Multilevel 5 level & 44.83 & 100 & 15.77 & 11.95 & 13.21 \\
\hline
\end{tabular}


Table 2. Comparison of Torque Characteristics for Two Level and Multi Level

Constant Speed and Constant Torque

Variable Speed and Variable Torque
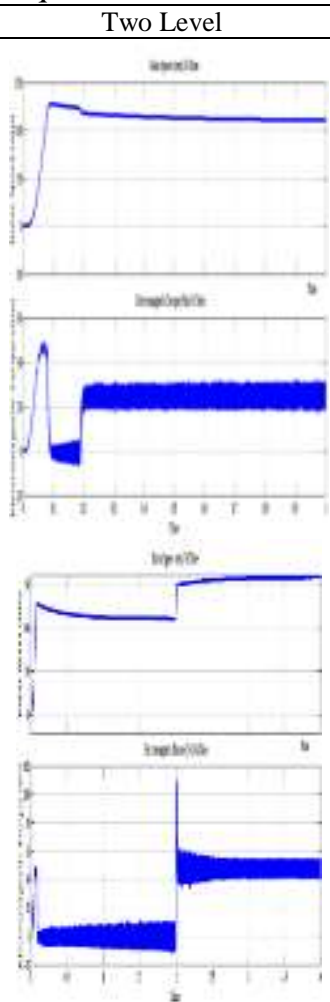
Multi Level
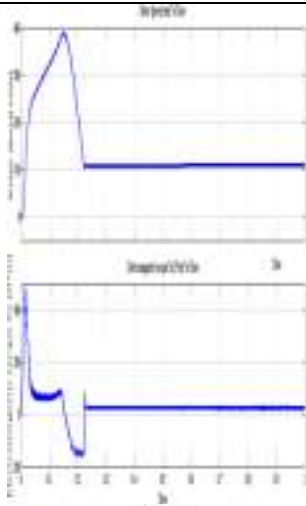

$\ln ^{n}$

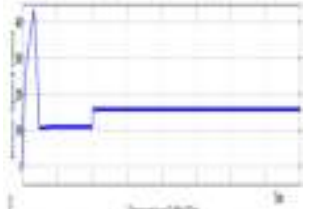

toming

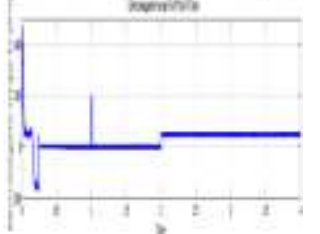

Table 3. Various Output Parameters of Two and Five Level Inverter at the Stating 0.0 to 0.2 and Apply Torque at 2 Second

\begin{tabular}{|c|c|c|c|c|}
\hline \multirow[b]{2}{*}{ Parameters } & \multicolumn{2}{|c|}{ Two Level Inverter } & \multicolumn{2}{|c|}{ Five Level Inverter } \\
\hline & $\begin{array}{c}\text { Without } \\
\text { load }\end{array}$ & With Load & $\begin{array}{c}\text { Without } \\
\text { load }\end{array}$ & With Load \\
\hline Torque in N-m & 48 & 109 & 469 & 54 \\
\hline Speed & 127 & 157 & 430 & 157 \\
\hline $\begin{array}{c}\text { Max Rotor } \\
\text { Current (Amp) }\end{array}$ & 37 & 37 & 246 & 33 \\
\hline $\begin{array}{c}\text { Max Stator } \\
\text { Current } \\
\text { (Amp) }\end{array}$ & 48 & 40 & 252 & 35 \\
\hline THD & \multicolumn{2}{|c|}{$86.80 \%$} & \multicolumn{2}{|c|}{$44.83 \%$} \\
\hline
\end{tabular}

\section{CONCLUSION}

A voltage regulated PWM voltage source inverter has been controlled for achieving vector control for controlling of squirrel cage induction motor. The output of the controlled converter has been fed to voltage regulated PWM voltage source inverter through a DC-link. Speed response, less overshoot, high rise time, small steady state errors and stability of system under variable speed characteristics has been achieved through MATLAB environment. The result of the THD is less for five level inverter than that of two level inverter. For reducing the switching losses and improve conversion efficiency for five level inverter.

\section{REFERENCES}

[1] Pichai Aree, Analytical approach to determine speed-torque curve of induction motor from manufacturer data, International Electrical Engineering Congress, IEECON 2016, March 2016.

[2] Rakesh Singh Lodhi, Payal Thakur, Performance \& Comparison Analysis of Indirect Vector Control of three Phase Induction Motor, "International Journal of Emerging Technology and Advanced Engineering," vol. 3, no. 10, pp. 716-724, October 2013.

[3] Bimal K Bose, Modern Power Electronics and AC Drives, Third edition Pearson Education, India 2007

[4] Peter Vas, Vector Control of AC Machines, Oxford University Press, New York, 1998. 
[5] R.Krishan, Electric motor drives modelling, analysis \& control, Paper back, Prentice Hall, New Jersey, 2001.

[6] J.Vithayathil, Power Electronics: principles and applications, First Edition, McGraw Hill, New York, 2010.

[7] N. Mohan, T.M. Undeland and W. P. Robbins, Power Electronics: Converters, Applications, and Design, 1989.

[8] P.C. Krause, Analysis of Electric Machinery, IEEE Press, New York, 2004.

[9] Nguyen Phung Quang, Jörg-Andreas Dittrich, Vector Control of Three-Phase AC Machines, Springer 2008.

[10] R.W. Erickson and D. Maksimović, Fundamentals of Power Electronics, Second Edition, Springer, 2005.

[11] M.H.Rashid, Power Electronics: Circuits, Devices and Applications, Third Edition, Prentice Hall of India, 2004.

[12] P.C.Sen, Principles of Electric Machines and Power Electronics, New York, 1996

[13] Bimal K. Bose, Power Electronics and Variable Frequency Drives, IEEE Press, New York 1997

[14] Ned Mohan, Power electronics and Drives, Paperback, Mnpere, Minneapolis USA 2001.

[15] Chee-Mun Ong, Dynamic Simulation of Electric Machinery, Second Edition Prentice Hall New Jersey 1998.

[16] L. Umanand, Power Electronics: Essentials \& Applications, First Edition, Wiley India Pvt Ltd, 2009.

[17] S.T. Karris, Introduction to Simulink with Engineering Applications, Orchard Publications, 2011. 